\title{
AGAPEIC THEISM: PERSONIFYING EVIDENCE AND MORAL STRUGGLE
}

\author{
PAUL K. MOSER \\ Loyola University Chicago
}

\begin{abstract}
The epistemology of monotheism offered by philosophers has given inadequate attention to the kind of foundational evidence to be expected of a personal God whose moral character is agapeic, or perfectly loving, toward all other agents. This article counters this deficiency with the basis of a theistic epistemology that accommodates the distinctive moral character of a God worthy of worship. It captures the widely neglected agonic, or struggle-oriented, character of a God who seeks, by way of personal witness and intentional action, to realize and manifest agape among humans who suffer from selfishness. In doing so, the article identifies the overlooked role of personifying evidence of God in human moral character formation. In agreement with some prominent New Testament themes, the new perspective offered ties the epistemology of monotheism to robust agapeic morality in a way that makes such epistemology ethically challenging for inquirers about God's existence. Accordingly, such theistic epistemology will no longer be a candidate for ethically neutral, spectator reflection.
\end{abstract}

\section{INTRODUCTION}

Notoriously, philosophers and theologians have tried to prove God's existence by various sorts of arguments, many of which are remarkably elaborate. The list includes cosmological, teleological, ontological, moral, and psychological arguments of different kinds, among others. None of these arguments has won the day with a consensus among competent observers; as a result, controversy proceeds apace among philosophers and theologians. This article takes a new approach by focusing on what would be God's approach to self-manifestation. Instead of focusing on our formulating arguments for God's existence, we shall focus on what kind of evidence, or witness, God would supply in order to reveal and 
authorize God's personal reality, moral character, and relevant purposes to humans.

We shall see how God can witness to God's reality for us, even if we humans cannot witness to God on our own. This approach accommodates the compelling fact that God would need to take the initiative in supplying evidence of divine reality to humans. If God is inherently personal and loving toward persons, as some versions of Jewish-Christian monotheism suggest, we should expect direct evidence of divine reality to be more akin to an authorizing personal witness than to a logical proof. In being non-personal, a logical proof lacks a personal character and personal agency and therefore lacks love toward persons. Logical proofs, and arguments in general, can affirm divine personal love, but they cannot directly manifest it, because they do not themselves have personal love in the way that personal witnesses can and sometimes do. They are not a living personal agent in the way God is, if God exists. Direct evidence of God would include direct evidence of a living personal agent, because only a living personal agent can directly reveal a living personal agent. Philosophers and theologians have neglected this important consideration, but this article counters this neglect.

\section{BEGINNING WITH THE TITLE “GOD”}

Discussions about God's existence rarely pause long enough to clarify what kind of exalted being, particularly what kind of personal moral character, is under discussion. The result is either an unacceptably vague conception of God or a distorted conception of God that misrepresents what role the term "God" plays in traditional monotheism. According to a classic monotheist use, the term "God" is an honorific title that requires worthiness of worship in its title holder. In this use, the term "God" is not a proper name and therefore can fail to have a referent, or denotation.

Although a person can worship pretty much anything, including himself or herself, worthiness of worship sets a maximally high moral standard. It requires the moral perfection of the one worthy of worship. To be worthy of worship is to be worthy of full, unqualified commitment. If, however, one is morally deficient in any way, then one will not be worthy of such exceptionless commitment. One will then be worthy at most 
of qualified commitment, given one's moral deficiency in some area. As a result, one will have to be free of moral deficiency, that is, be morally perfect, to be worthy of worship. A holder of the title "God," then, will be morally perfect.

Moral perfection is the rarest of valuable features in our morally troubled world. No mere human emerges as a viable candidate for moral perfection, and this seems to be one of the few truths about the world that reflective humans can agree on. Even if some humans set moral perfection as their life goal, and work hard to achieve it, no mere human can plausibly claim to have reached that goal in this earthly life. In seeking what is morally best for humans, however, God would seek moral perfection for them. If God sought something less than moral perfection for humans, this would invite the charge of God's being morally lax, in virtue of settling for something that falls short of what is morally ideal for humans. Such moral laxness would call into question God's being perfectly loving toward humans and therefore God's being worthy of worship.

Exactly how God would seek moral perfection for humans is hard, if not impossible, for cognitively limited humans to specify a priori, in the abstract. We may have to "look and see" in actual human experience and history to acquire the needed information. Human experience and history may surprise us on this matter. We can plausibly infer that mere humans fail and will fail to acquire moral perfection on their own, but God would have various alternatives to counter this widespread failure. We do well to look at human experience and history to see how, if at all, God seeks to counter human moral failure for the sake of eventual human moral perfection. Therefore, we should not automatically expect human inquiry about God to proceed solely a priori, just on the basis of reason and definition. The relevance of human experience and history merits careful attention here. The key question now is this: what kind of experience would be relevant to God in a manner that suitably indicates God's existence or presence or even God's absence?

In seeking what is morally best for humans, God would seek to communicate somehow with humans. The desired divine communication would aim to be morally challenging, and thus redemptive, in virtue of bringing humans not only information about God but also acquaintance with God's moral character. The latter acquaintance would enhance human motivation toward conformity with God's moral character, and 
would prevent relevant ideas about God from being purely speculative. John Baillie explains:

What is directly revealed to us ... is not truths or doctrines about God but God himself. Our doctrines about God are always secondary to our direct finding of God in the realities of our experience, and are never wholly adequate to that finding or wholly exhaustive of its meaning. God does not [just] communicate with us: He does something far better-He communes with us. Not the communication of propositions but the communion of spirits is the last word about divine revelation (1929, pp. 114-15; cf. Baillie 1962, pp. 15-18).

Such communion would be de re, and not merely de dicto, in virtue of being directly agent-to-agent (or person-to person), and not just agentto-proposition. It would involve the direct acquaintance of one personal agent with another, even if human beliefs accompany the acquaintance. Accordingly, God's witness of divine reality to humans need not be altogether propositional; it can include a non-verbal, non-propositional component.

If God's inherent moral character is one of unselfish love, or agape, toward others and is the personal power yielding such love among humans, then the salient basis is set for human acquaintance and communion with God. Accordingly, Baillie remarks: “The Christian's finding of God in Christ is but the fulfillment of faith's older finding of Him in all love and goodness, wherever these are revealed to our human eyes. God is love. Where love is, there God is" (1929, p. 119). This approach gives us a definite, realizable standard for human experience of God's moral character rather than of some alternative, such as a harmful counterfeit. Humans experience God's moral character whenever they experience agape, even if humans play a cooperative role, at least de re, in the provision of agape in many cases. Indeed, if we fail to find evidence of God's moral character in agape, we may fail to find it anywhere.

We find a clear connection between God and agape suggested in various parts of the New Testament. For instance, according to 1 John 4:78,16: " . . love is of God, and he who loves is born of God and knows God. He who does not love does not know God; for God is love . . . God is love, and he who abides in love abides in God, and God abides in him" (RSV). The two striking claims that "God is love" and that "love is 
of God" suggest a key role for agape in human acquaintance with God. The heart of agape is one's unselfishly willing what is good for someone, and such willing involves a distinctive kind of power: the power to love others unselfishly. If "love is of God," this power is not just a human product, even if humans play a direct incomplete role in some instances of its production. In that case, agape arises instead, at least in part, from the power of God, whose moral character is inherently and perfectly loving. The suggestion, then, is that if one wants to see what God is like in action, one should look to agape in action, even if humans are directly involved in some cases.

As suggested, a morally perfect God would seek what is morally best for humans, even what is morally perfect for them. This effort would include a divine redemptive call to humans to be conformed to God's moral character in willing cooperation with God's revealed purposes. The divine call would not be coercive, so long as God allows for human agency in response to God, and it could come in various ways. It could come through humans who relay the call, or it could come from God without human intermediaries. It also could come through circumstances that involve humans, such as failed human relationships, even when human intermediaries do not figure directly in the call itself. Accordingly, God would have various ways to extend a redemptive call to humans, and we cognitively limited humans should not consider ourselves to be in a position to comprehend fully all of the ways God can extend such a call. Even so, God would seek to call at least receptive humans to conformity with God's moral character, for their own good. This would exonerate God from a charge of moral laxness in relating to humans.

\section{THEISM AS AGAPEIC AND AGONIC}

Like divine redemption in general, God's redemptive call would be agonic in its intended effects, owing to a struggle to realize and manifest divine agape among all persons. In other words, it would be a call to struggle against whatever is anti-God (that is, whatever opposes God's moral character) and for whatever honors God. If divine agape is agonic in this manner, we should expect God and direct evidence of God to be likewise agonic. In particular, we should expect such evidence to aim to 
have its recipients become similarly agonic in a struggle to realize and manifest divine agape among all persons. This would put evidence of God in a profoundly new light.

The apostle Paul characterizes God and divine redemption as agonic in a number of his letters. For instance, after referring to God as "the one who calls you" (Galatians 5:8; cf. 1:6), Paul remarks that "the desires of the [human] flesh are against the Spirit [of God], and the desires of the Spirit are against the flesh; for these are opposed to each other" (Galatians 5:17, RSV; cf. Romans 7:22-25). He then identifies "works of the flesh," not with deeds of the body, but instead with immoral actions and attitudes in conflict with God's moral character: idolatry, jealousy, drunkenness, lewdness, fornication, and so on (Galatians 5:19-21).

In contrast, the traits of "the Spirit" are the distinctive features of God's worship-worthy moral character: "love (agape), joy, peace, patience, kindness, goodness, faithfulness, gentleness, self-control” (Galatians 5:22-23, RSV). In Paul's portrait, God's redemptive call is a call to struggle against the immoral "works of the flesh" and for (our manifesting) the features of God's moral character. Indeed, Paul thinks of God's Spirit as offering to humans not only a personal witness to God as Father (Romans 8:15-16; cf. 2 Corinthians 2:22, 5:5), but also the divine power to "put to death" their immoral deeds antithetical to God's moral character (see Romans 8:13). Accordingly, God not only calls humans to struggle but also offers the power humans need to undertake the struggle. Paul likens his own redemptive struggle with the churches of Galatia to childbirth: “. . I I am again in the pain of childbirth until Christ is formed in you" (Galatians $4: 19$, NRSV). The struggle, according to Paul, is for humans willingly "to be conformed to the image of [God's] Son" (Romans 8:29). We shall clarify how this struggle proceeds, in order to identify the distinctive kind of direct evidence we should expect of an agonic God.

Instead of a mere principle-oriented approach, Paul takes a personifying approach to the redemptive struggle by (a) identifying the person of Jesus, and not just moral principles, as the self-giving manifestation of God (see Philippians 2:4-11; cf. Colossians 1:15), and (b) endorsing the standard of a human person's "becoming like him [=Jesus]" in certain ways (see Philippians 3:10; cf. Romans 13:14). In accordance with the personifying standard that Jesus "emptied himself" for the sake of God (Philippians 2:7), Paul portrays his own redemptive struggle as follows: 
Whatever gain I had, I counted as loss for the sake of Christ. Indeed I count everything as loss because of the surpassing worth of knowing Christ Jesus my Lord. For his sake I have suffered the loss of all things, and count them as refuse, in order that I may gain Christ and be found in him, not having a righteousness of my own, based on law, but that which is through faith in Christ, the righteousness from God that depends on faith; [in order] that I may know him and the power of his resurrection, and may share his sufferings, becoming like him in his death, that if possible I may attain the resurrection from the dead. Not that I have already obtained this or am already perfect; but I press on to make it my own ... (Philippians 3:7-12, RSV).

Paul's redemptive struggle is both negative and positive: it is against all things that challenge God's supremacy, and it is for knowing God and his resurrection power, as exemplified in the resurrection of the crucified Jesus. Ultimately, then, the redemptive struggle is a struggle for humans to participate in God's life-giving resurrection power anchored in selfgiving divine agape. (On the role of "mutuality" between Jesus and his followers in this connection, see Longenecker 2003.)

Paul thinks of God as offering morally powerful righteousness to humans (including a right relationship with God) as a perfectly free gift of divine "grace," without human merit or earning (see Romans 3:21-25, 4:4-5). Even so, the human reception of this powerful free gift, through human faith (or trust) in God, is centrally agonic, replete with human struggle, including the struggle to put God first over all other things. The latter point is widely neglected among interpreters of Jesus and Paul, and this hinders a needed understanding of faith, or trust, in God as crucially involving human struggle, beyond human thinking, believing, and reasoning.

Paul's agonic approach to divine redemption of humans is suggested by the following remark: "[God] has graciously granted you the privilege not only of believing in Christ, but of suffering for him as well - since you are having the same struggle (agōn) that you saw I had... (Philippians 1:29-30, NRSV). The redemptive struggle of suffering emerges also in the Pauline letter to the Colossians: "I rejoice in my sufferings for your sake, and ... I complete what is lacking in Christ's afflictions for the sake of his body, that is, the church" (1:24, RSV; cf. 2:1). Even if Paul is not directly responsible for the letter to the Colossians (and the jury is still 
out on this), an astute student of his teaching is, as suggested by its clear parallels with Paul's remarks in 2 Corinthians 1:5, 4:8-11.

Paul's acknowledgment of the key role of human struggle in receiving and sharing the power of divine redemption fits well with his otherwise puzzling injunction: “... work out your own salvation with fear and trembling; for God is at work in you, both to will and to work for his good pleasure" (Philippians 2:12-13, RSV; cf. Romans 13:12, 2 Corinthians 6:7, 10:4). Paul's injunction is definitely not the following: work to earn, or to merit, your salvation from God. Instead, his key idea is that people are called to struggle, even in suffering, to receive and thereby to share the power of divine redemption freely on offer. We may understand the following remark attributed to Jesus in the same vein: "Struggle to enter through the narrow door [to God's kingdom]; for many, I tell you, will try to enter and will not be able" (Luke 13:24; cf. Matthew 7:13-14). The struggle in question enhances the cooperative receptivity of those who seek to appropriate God's powerful free gift of a life of agape in accordance with God's moral character.

Let's use the word "temptation" for whatever invites one to be antiGod in some way, in virtue of opposing God's moral character, whether in attitude or in action. Ethelbert Stauffer observes:

[Human] thinking that treads the road [of] faith [in God] has to fight a daily battle with temptation .... [A]gain and again the way is beset with puzzles and darkness.... [I]n temptation, [however], theology passes into prayer, that asks God himself for the answer to the enigma of our historical experiences (cf. Psalm 73:2, 15ff., 28). Only thought that prays can lead beyond the temptation and take us from one certainty to another" [cf. Job 27:1, 42:8] (1955, p. 175).

Stauffer adds an important component to an account that offers a personifying agonic approach to the divine redemption of humans. We may call this component "kenotic prayer."

The adjective "kenotic" stems from the Greek verb (kenoō) that underlies the idea, in Philippians 2:7, of Jesus emptying himself of his own preferences in humble obedience to his divine Father, even to the extent of death on the cross for others. (On this important idea, see Gorman 2001, pp. 253-59, 2009, pp. 9-39.) We may think of the redemptive struggle, including its accompanying suffering, as being intended by 
God to prompt humans to engage in kenotic prayer to God, beyond mere thinking, believing, and reasoning. A perfectly loving God would want people to call on God, in kenotic prayer, for purposes of human redemption via cooperative fellowship with God. Such prayer would enhance one's receptivity to the new life offered by God, in virtue of one's emptying oneself of ambitions contrary to God's purposes. (For some relevant philosophical discussion, see Stump 1979.)

A salient example of kenotic prayer is found in Jesus in Gethsemane, just before his arrest and crucifixion. For good reason, the situation is traditionally called Jesus's "agony in the Garden," in the light of his painful struggle in the face of a torturous death. Some ancient versions of Luke's Gospel report that "his sweat became like great drops of blood falling down on the ground" (Luke 22:44, NRSV). His agonizing prayer is represented in Mark's Gospel as follows: "Abba, Father, for you all things are possible; remove this cup from me; yet, not what I want, but what you want" (Mark 14:36, NRSV; cf. Matthew 26:39, Luke 22:42). This prayer is agonic and kenotic: agonic, because Jesus struggles against his initial preference and for submission to God's will; and kenotic, because Jesus empties, or denies, his initial preference in order to obey God's call to self-giving obedience for the sake of others (cf. 2 Corinthians 8:9). Accordingly, we can think of the agonic and kenotic features of redemption as serving God's purpose to enhance human obedience toward God. This obedience contributes to the realizing and manifesting of divine agape among humans, and thereby to the human personifying of God's moral character.

A central theme of Paul's redemptive message is that "God was in Christ reconciling the world to himself" (2 Corinthians 5:19, RSV). Accordingly, we may think of God himself as struggling, even suffering, in redemption in order to identify with humans in need of divine redemption. (For discussion of divine suffering, see Moltmann 1981, chapter 2, Fretheim 1984, Fiddes 1988, and Wolterstorff 1988.) In this perspective, God is engaged in a struggle to undermine evil for the benefit of humans, without destroying human agency or protecting humans from all evil. God is, in short, agonic because agapeic.

Jesus thought of his controversial ministry as guided by a divine struggle against evil. For instance, he remarks that ".. if it is by the finger of God that I cast out the demons, then the kingdom of God has come 
to you" (Luke 11:20, NRSV; cf. Matthew 12:28, Mark 3:27). Accordingly, Jesus attributes the power behind his agape-based agonic ministry to God. In the language of John's Gospel, “... the Son can do nothing on his own, but only what he sees the Father doing" (John 5:19, NRSV; cf. John 8:28). In this portrait, the Jewish-Christian God is agonic for the sake of human redemption aimed at the realization of divine agape among all persons. This divine struggle intends to be life-giving to all humans, who cannot supply the needed agapeic life on their own. We need to consider the relevant kind of agape more closely.

\section{PERSONIFYING AGAPEIC EVIDENCE}

We have characterized agape broadly as one's unselfishly willing what is good for someone, and we have identified agape as being at the heart of God's worship-worthy character. Divine love, however, is peculiar in its scope: it extends not only to friends of God, but also to resolute enemies of God. Such unselfish love is arguably a requirement of a morally perfect, worship-worthy character. Jesus acknowledges divine enemylove and a corresponding requirement of human enemy-love, as follows: "Love your enemies and pray for those who persecute you, so that you may be children of your Father in heaven; for he makes his sun rise on the evil and on the good" (Matthew 5:44-45, NRSV). A parallel remark attributed to Jesus in Luke's Gospel is that "[God] is kind to the ungrateful and the wicked. Be merciful, just as your Father is merciful" (Luke 6:35-36, NRSV). Such enemy love, including praying for one's enemies, is rarely endorsed by humans, even in the arena of longstanding religions. (For a possible move in this rare direction, see Proverbs 25:21-22; cf. Romans 12:20-21. For discussion, see Furnish 1972, chapter 1, Klassen 1984, chapter 4, Outka 1992, and Topel 2001, chapter 5.)

Paul straightforwardly acknowledges divine enemy-love as follows: "God proves his love (agape) for us in that while we were still sinners Christ died for us. ... [W] [Wile we were enemies, we were reconciled to God through the death of his Son ..." (Romans 5:8,10, NRSV). It follows from Paul's remarks that God proves his redemptive love even for his enemies. Paul regards himself as a former enemy of God who was unworthily shown God's redemptive love, or grace (see Galatians 1:13, 15; 
cf. 1 Corinthians 15:8-10). Such divine love prompts the following kenotic response from Paul: "I will boast all the more gladly of my weaknesses, so that the power of Christ may dwell in me. Therefore I am content with weaknesses, insults, hardships, persecutions, and calamities for the sake of Christ; for whenever I am weak, then I am strong" (2 Corinthians 12:910 , NRSV). God's unique power of agape, even toward enemies, is shown to be unique and enduring against the backdrop of human weaknesses of various sorts, particularly moral weaknesses. Accordingly, Paul values divine power over human power as the needed basis of human faith in God (see 1 Corinthians 2:3-5; cf. 2 Corinthians 4:7-11, 1 Thessalonians 1:5).

Enemy love figures centrally in God's witness to God's reality, because it is salient evidence of God's unique moral character and abiding power. This evidence goes beyond propositions, arguments, and even experiences to distinctive personifying evidence. That is, it can reside in the moral character of a person in virtue of this character's being formed by divine power to reflect God's moral character of agape, even toward enemies. This consideration gives definite meaning to the present talk of personifying evidence in contrast with propositions, arguments, and experiences.

The relevant idea of personifying evidence is suggested in John's Gospel by the notion of a person's being "born of the Spirit" of God (John 3:6), and in Paul's letters by the assumption that "if anyone is in Christ, there is a new creation" (2 Corinthians 5:17, NRSV; cf. Galatians 6:15). Paul contrasts this new creation with "our old self . . enslaved to sin" (Romans 6:6, NRSV), thus suggesting that it includes a new self, a new "inmost self" that will "delight in the law of God" (Romans 7:22, NRSV; cf. Romans 8:4). He thinks of this new creation as one's being spiritually (but not yet bodily) raised, or resurrected, to "walk in newness of life" (Romans 6:4, RSV; cf. Colossians 2:12). Accordingly, he speaks of the Roman Christians as "those who have been brought from death to life" (Romans 6:13, NRSV). The new self in question corresponds to the divine promise of Ezekiel 36:26 to God's people: "A new heart I will give you, and a new spirit I will put within you ..." (NRSV; cf. 11:19, Jeremiah 31:33). The promise offers the divine gift of a new human center of motivation, a center that agrees with God's moral character of agape toward all others. (For relevant discussion, see Hubbard 2002.)

Paul thinks of the new self as the willing recipient of God's agape given through God's Spirit: "God's love has been poured into our hearts 
through the Holy Spirit that has been given to us" (Romans 5:5, NRSV). In addition, he thinks of divine agape in humans as the primary "fruit of the Spirit" of God, involving one's being "led by the Spirit" of God (Galatians 5:18,22; cf. Romans 8:1-5). Even more to the point, he regards divine agape as a ground for hope in God that precludes our being disappointed by such hope (Romans 5:5). We plausibly can treat this as a $\operatorname{cog}$ nitive ground for human hope in God, and not just as a causal ground. That is, divine agape as an experienced transformative gift is salient evidence of God's presence in one's life, although this important consideration is overlooked by most philosophers and theologians. When such evidence is delivered directly by God's personal Spirit as representative of God's moral character, it takes the form of an authorizing personal witness to God's reality rather than a logical proof (see Romans 8:15-16, 2 Corinthians 2:22, 5:5; cf. Moser 2008, chapter 2).

According to John's Gospel, divine love in one's moral character is an indicator of one's being a genuine child of God and disciple of Jesus, who remarks as follows to his followers: "Just as I have loved you, you also should love one another. By this everyone will know that you are my disciples, if you have love (agape) for one another" (John 13:34-35; cf. 1 John 3:1,14,18-19). The agapeic evidence identified by John and Paul rests on the personally experienced power of personal divine agape and thus is person-oriented throughout. These considerations fit well with the following observation by F.X. Durrwell: “... redemption as a whole is a personal work. It is so in Christ who, in his death and resurrection, is himself salvation; it is so in the church which shares in salvation through fellowship with Christ in his death and resurrection" (1972, pp. 167-68). The salient evidence in such fellowship is more akin to an authorizing personal witness from God than to a logical proof or any other kind of argument.

In the wake of Jesus (Matthew 5:38-48, Luke 6:27-36), both John and Paul think of divine agape as extending to recipients beyond the followers of Jesus, to the whole world of persons, including enemies of God (cf. John 3:16, Romans 5:6-10, 12:14-21). We may distinguish, however, between God's intended human recipients of such love and the willingly transformed human bearers of divine love. God's intended human recipients can include self-avowed enemies of God, whereas the willingly 
transformed human bearers are no longer enemies of God, because they have yielded, if imperfectly, to God's call to redemption.

Willing human bearers of divine agape manifest personifying evidence of God's reality, because they are personal witnesses to the transforming power of divine agape among humans (including themselves) and thus to the reality of God's moral character. Such personal witnesses, according to Paul, "are being changed into [God's] likeness from one degree of glory to another" (2 Corinthians 3:18, RSV). As a result, Paul refers to the Corinthian Christians themselves as "a letter from Christ ... written ... with the Spirit of the living God ... on tablets of human hearts" (2 Corinthians 3:3, RSV). Such personifying evidence goes beyond any argument or logical proof in its power of personal communion, person-to-person. Being personal, it conveys God's personal moral character to a person in a way that no argument or logical proof (being nonpersonal) can. Even so, one can use an abductive, explanatory argument to challenge skeptics about divine reality, on the basis of the best available explanation of the human transformation in question (see Moser 2008, pp. 126-43, 2010, chapter 4; cf. Wiebe 2004, chapter 3). Such an argument, however, must not be confused with the basic experiential evidence for God's existence supplied by transformative agape. ( For an account of basic, foundational evidence that avoids a confusion of such evidence with an argument but accommodates the important role of abduction, see Moser 1989.)

The divine witness in agape is a witness in action, in personified redemptive action, as Paul stresses in his understanding of the cross (see Romans 5:8; cf. 3:24-26). God could present merely claims and arguments to humans, but such an intellectualist strategy would omit something that is morally, motivationally, and personally important: personto-person communion on the basis of God's moral character of agape even toward enemies. As a result, a perfectly loving God would not settle just for claims and arguments by way of revelation. God would promote the kind of personal witness to God's reality that resides in personifying evidence reflective of God's moral character. God would draw near to humans in a personal manner that goes beyond any claims, logical proofs, or arguments in general. The result, as suggested, would be an authorizing divine witness, from a cognitive authority, to divine reality for humans. 
In the epistemologies of Paul and John, Jesus Christ is the paradigm of personifying evidence of God, given that he is "the likeness of God" (2 Corinthians 4:4, RSV; cf. Colossians 1:15) and the one, "in the bosom of the Father, [who] has made [God] known" (John 1:18, RSV). Accordingly, John's Gospel portrays Jesus as saying: "Whoever has seen me has seen the Father. How can you say, 'Show us the Father'?" (John 14:9, NRSV), and Paul speaks of "the knowledge of the glory of God in the face of Christ" (2 Corinthians 4:6, NRSV). Jesus himself emerges therefore as personifying evidence of God, in virtue of being an authoritative and authorizing personal witness to God.

We should clarify what exactly God, as worthy of worship, would seek to reveal to humans. If the answer is, as suggested, "God's personal moral character," we can see why God would rely on an irreducibly personal witness for self-revelation, rather than on mere information or mere arguments. The best witness to a personal moral character is itself personal and hence goes beyond mere information and mere arguments. This simple but crucial lesson is widely neglected among philosophers, theologians, and other theorists. In bringing it to center stage, we can begin to make sense of the kind of direct, foundational evidence and self-manifestation to be expected of a God worthy of worship. We also can see why an authorizing self-witness from God is better suited as direct evidence in this case than a mere logical proof or any other kind of mere argument. (For the bearing of this lesson on the traditional theistic arguments, in connection with divine hiding, see Moser 2010, chapter 3; cf. Richardson 1966, chapter 6.)

Personified evidence from God's witness has distinctive features that cannot be fully captured by claims and arguments. In particular, claims and arguments cannot exhaust divine agape directly shown, or manifested, to a person by a personal witness who personifies agape. Accordingly, Paul speaks of "the manifestation of the truth" regarding divine redemption, where this manifestation includes the following: "commending ourselves to the conscience of every person before God" (2 Corinthians $4: 2$, italics added). His approach concerns person-based manifestation of evidence regarding God's redemptive intervention in Jesus. This manifestation is twofold according to Paul: "[We are] always carrying in the body the death of Jesus, so that the life of Jesus may also be manifested in our bodies. For while we live we are always being given up to death 
for Jesus's sake, so that the life of Jesus may be manifested in our mortal flesh" (2 Corinthians 4:10-11, RSV; cf. 6:9). This sums up the existential core of "dying and rising with Christ."

The "life of Jesus" includes the resurrection power that Paul sought to know (see 2 Corinthians 4:14, Philippians 3:10; cf. Furnish 1984, pp. 283-84, Savage, 1996, pp. 177-78, and Byrnes 2003, pp. 61-71). This power is the same divine power of self-giving love that motivated Jesus to obey God even to the extreme of accepting death on a criminal's cross. As a result, Paul can say to the churches of Galatia that in his ministry "Jesus Christ was publicly portrayed as crucified" before their eyes (Galatians 3:1, RSV). A witness who manifests the death of Jesus also manifests the resurrection life of Jesus, if only in enduring suffering without relinquishing agape for others. More specifically, one's dying-and-rising with Jesus is the way to appropriate and to manifest divine agonic agape. It yields evidence, in a personal witness, of divine reality and presence, and it is the existential reality to which Christian faith and hope in God commit a person (cf. Byrnes 2003, pp. 121-22, 283-85).

\section{CONCLUDING IMPEDIMENTS}

We now can identify three human impediments to acknowledging and appropriating God's personal witness. The first impediment involves neglecting the fact that the personifying divine evidence in question has a diachronic character in human witnesses that involves development over time. Philosophers and theologians rarely look for evidence of God with such a diachronic character, and assume instead that evidence of God would be synchronic, available at a moment. In contrast, we may regard the aforementioned developmental feature in willing humans as spiritual maturation that includes one's becoming increasingly true to God, in communion with God.

A person's believing truths about God falls short of a person's becoming true to God in virtue of being conformed to God's moral character, in a struggle of dying and rising with Jesus. The latter conformation yields personifying evidence of God in a person over time. Human witnesses to God, then, owe their witnessing power (to God) to their becoming true to God over time and therefore, ultimately, to God's power. This is 
no surprise, given that the basic empowering moral character for divine agape is God's character. Human witnesses to God are but cooperative beneficiaries of this divine power and evidence.

The second impediment is perhaps the most common: it is human unwillingness to undertake an agonic life toward agape-oriented character formation. Kierkegaard remarks bluntly: "you must die to your selfishness, ... because it is only through your selfishness that the world has power over you ... But naturally there is nothing a human being hangs on to so firmly_indeed with his whole self! —as to his selfishness!" (1851, p. 77). Human selfishness is, of course, antithetical to agape and therefore to a personified witness to the reality of divine agape. A refusal to die to selfishness is, in effect, a refusal to live an agape-oriented life and thus to witness personally to the reality of the divine source of agape.

Kierkegaard seriously distorts the truth at hand with this claim: "before the Spirit who gives life can come, you must first die to [selfishness]" (1851, p. 79; cf. p. 81). As suggested previously, the power of God's Spirit is offered to humans to "put to death" selfishness and other human traits contrary to God's moral character (see Romans 8:13). Accordingly, we might say that even human repentance is an empowered gift offered by God. A perfectly loving God, in other words, would offer to willing humans the power to "die to" selfishness as the way to realize cooperative life with God in agape toward others. Humans therefore would not be left, as Kierkegaard suggests, with their own meager power to purify themselves of selfishness before God's Spirit could supply God's life-giving power. Instead, God's life-giving power would be available to humans to set aside habitual selfishness for the sake of cooperative life with God. Kierkegaard mistakenly offers human self-purification as a precondition for, rather than a beneficiary of, the arrival of God's life-giving power. This is a recipe for frustration and excess severity, given human weakness. (For further discussion of Kierkegaard on God and agape, see Moser and McCreary 2010; cf. Walsh 2009, chapter 6.)

A third impediment is a close cousin to selfishness: human selfrighteousness, the attitude that one is morally self-adequate, even before God. This is a kind of moral pride that readily takes the credit for the agape manifested in one's life, thereby omitting a crucial role for God in this connection. It endorses human moral self-achievement over either the need or the availability of the gift of divine grace. Accordingly, such 
pride obscures the need for kenosis in a human life relative to God, and therefore clouds the personal witness of God to God's character of agonic agape toward humans. In particular, it resists the humble but struggling human reception of this witness in one's own moral character. Such reception is cast off for the sake of prideful human achievement in the moral domain. The agonic witness of divine grace, then, is at odds with human self-righteousness, morally and cognitively. (For relevant discussion, see Niebuhr 1964, chapters 4-5.)

In conclusion, we have identified agapeic theism as offering a widely neglected but distinctive approach to direct evidence of divine reality. Such theism characterizes this evidence as existentially significant, in virtue of its call for agonic human participation in, and thus personified witnessing to, the divine life of agape toward others. We now can see why and how the direct evidence of an agapeic and agonic God is morally significant in a manner worthy of more attention among philosophers and theologians. Religious epistemology, accordingly, can come to life in agapeic theism as agonic. It thus can move beyond mere reflection and discussion to the key role of human struggle for agape toward others. A worship-worthy God would foster such action-directed epistemology, for the vital good of all concerned.

\section{BIBLIOGRAPHY}

Baillie, John. 1929. The Place of Jesus Christ in Modern Christianity. New York: Charles Scribner's Sons.

. 1962. The Sense of the Presence of God. London: Oxford University Press.

Byrnes, Michael. 2003. Conformation to the Death of Christ and the Hope of Resurrection. Rome: Gregorian University Press.

Durrwell, F.X. 1972. The Mystery of Christ and the Apostolate, trans. Edward Quinn. London: Sheed and Ward.

Fiddes, Paul. 1988. The Creative Suffering of God. Oxford: Oxford University Press.

Fretheim, Terence. 1984. The Suffering of God. Philadelphia: Fortress Press.

Furnish, Victor P. 1972. The Love Command in the New Testament. Nashville, Tenn.: Abingdon Press. 1984. II Corinthians: The Anchor Bible. New York: Doubleday. 
Gorman, Michael J. 2001. Cruciformity. Grand Rapids, Mich.: Eerdmans. 2009. Inhabiting the Cruciform God. Grand Rapids, Mich.: Eerdmans.

Hubbard, Moyer V. 2002. New Creation in Paul's Letters and Thought. Cambridge: Cambridge University Press.

Kierkegaard, Søren. 1851. For Self-Examination, trans. H.V. and E.H. Hong. Princeton: Princeton University Press, 1990.

Klassen, William. 1984. Love of Enemies. Philadelphia: Fortress Press.

Longenecker, Richard. 2003. "The Pauline Concept of Mutuality as a Basis for Luke's Theme of Witness.” In G. R. Wooden et al., eds., You Will Be My Witnesses, pp. 109-26. Macon, Ga.: Mercer University Press.

Moltmann, Jürgen. 1981. The Trinity and the Kingdom. New York: Harper \& Row.

Moser, Paul K. 1989. Knowledge and Evidence. Cambridge: Cambridge University Press.

.2008. The Elusive God: Reorienting Religious Epistemology. Cambridge: Cambridge University Press. 2010. The Evidence for God: Religious Knowledge Reexamined. Cambridge: Cambridge University Press.

Moser, Paul K., and Mark McCreary. 2010. "Kierkegaard's Conception of God." Philosophy Compass 5, pp. 127-35.

Niebuhr, Reinhold. 1964. The Nature and Destiny of Man, Volume 2: Human Destiny. New York: Charles Scriber's Sons.

Outka, Gene. 1992. "Universal Love and Impartiality." In E.N. Santurri and William Werpehowski, eds., The Love Commandments: Essays in Christian Ethics and Moral Philosophy, pp. 1-103. Washington, D.C.: Georgetown University Press.

Richardson, Alan. 1966. Religion in Contemporary Debate. Philadelphia: Westminster Press.

Savage, Timothy. 1996. Power through Weakness. Cambridge: Cambridge University Press.

Stauffer, Ethelbert. 1955. New Testament Theology, trans. John Marsh. New York: Macmillan.

Stump, Eleonore. 1979. "Petitionary Prayer." American Philosophical Quarterly 16, pp. 81-91.

Topel, L.J. 2001. Children of a Compassionate God. Collegeville, Minn.: Liturgical Press.

Walsh, Sylvia. 2009. Kierkegaard. Oxford: Oxford University Press.

Wiebe, Phillip. 2004. God and Other Spirits. New York: Oxford University Press.

Wolterstorff, Nicholas. 1988. "Suffering Love." In Thomas Morris, ed., Philosophy and the Christian Faith. Notre Dame, In.: University of Notre Dame Press. 